\title{
FADD protein release mirrors the development and aggressiveness of human non-small cell lung cancer
}

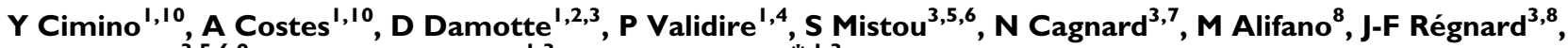 \\ G Chiocchia $^{3,5,6,9}$, C Sautès-Fridman ${ }^{1,3}$ and $L$ Tourneur T, $^{*, 3}$
}

'Centre de Recherche des Cordeliers, Equipe 13, Inserm UMRS 872, 75006 Paris, France; ${ }^{2}$ Senvice de pathologie, Hôtel-Dieu, AP-HP, 75004 Paris, France; ${ }^{3}$ Université Paris Descartes, 75006 Paris, France; ${ }^{4}$ Département d'anatomie pathologique, Institut Mutualiste Montsouris, 75014 Paris, France; ${ }^{5}$ Inserm, U 01 6, Institut Cochin, 75014 Paris, France; ${ }^{6}$ CNRS, UMR 81 04, 75014 Paris, France; ${ }^{7}$ Plateforme de bio-informatique Paris Descartes, 75015 Paris, France; ${ }^{8}$ Service de Chirurgie Thoracique, Hôtel-Dieu, AP-HP 75004 Paris, France; ${ }^{9}$ Senvice de rhumatologie, Ambroise Paré, AP-HP, 92100 Boulogne-Billancourt, France

\begin{abstract}
BACKGROUND: The need to unfold the underlying mechanisms of lung cancer aggressiveness, the deadliest cancer in the world, is of prime importance. Because Fas-associated death domain protein (FADD) is the key adaptor molecule transmitting the apoptotic signal delivered by death receptors, we studied the presence and correlation of intra- and extracellular FADD protein with development and aggressiveness of non-small cell lung cancer (NSCLC).

METHODS: Fifty NSCLC patients were enrolled in this prospective study. Intracellular FADD was detected in patients' tissue by immunohistochemistry. Tumours and distant non-tumoural lung biopsies were cultured through trans-well membrane in order to analyse extracellular FADD. Correlation between different clinical/histological parameters with level/localisation of FADD protein has been investigated.

RESULTS: Fas-associated death domain protein could be specifically downregulated in tumoural cells and FADD loss correlated with the presence of extracellular FADD. Indeed, human NSCLC released FADD protein, and tumoural samples released significantly more FADD than non-tumoural $(N T)$ tissue $(P=0.000003)$. The release of FADD by both tumoural and NT tissue increased significantly with the cancer stage, and was correlated with both early and late steps of the metastasis process.

CONCLUSION: The release of FADD by human NSCLC could be a new marker of poor prognosis as it correlates positively with both tumour progression and aggressiveness.

British Journal of Cancer (2012) 106, 1989-1996. doi:I0.1038/bjc.2012.196 www.bjcancer.com

(c) 2012 Cancer Research UK
\end{abstract}

Keywords: non-small cell lung cancer; biomarker; FADD; prognosis; release

Lung cancer is the deadliest cancer in the world. Non-small cell lung cancer (NSCLC), which includes adenocarcinoma (ADC), squamous cell carcinoma (SCC), and large cell carcinoma (LCC), represent $\sim 80 \%$ of the lung cancer. The usual therapy of NSCLC consists of surgical resection of the tumour possibly preceded or followed by chemotherapy or radiotherapy. Nevertheless, most patients have poor clinical outcome in spite of these treatments, in view of the tumour-node-metastasis (TNM; $\mathrm{T}=$ primary tumour, $\mathrm{N}=$ regional lymph nodes, $\mathrm{M}=$ distant metastasis) status (Mountain, 1997) of the patients on the day of surgery. Although the 5-year post-surgery survival rate is $>70 \%$ for T1N0M0 patients, it decreases to $10-30 \%$ when lymph nodes are invaded by tumour cells (N1-N2), and declines to $<5 \%$ in distant metastasis (M1). For these reasons, the need to unfold the underlying mechanisms of lung cancer aggressiveness is of prime importance.

It has been observed that functional FasL was expressed in most resected NSCLC cells (Niehans et al, 1997). Thus, NSCLC might

\footnotetext{
*Correspondence: Dr L Tourneur;

E-mail: lea.remy-tourneur@parisdescartes.fr

${ }^{10}$ These authors contributed equally to this work.

Received 20 January 2012; revised 2 April 2012; accepted I8 April 2012
}

have developed Fas-mediated apoptosis resistance mechanisms. Because FADD (Fas-associated death domain protein) is the key adaptor molecule transducing the apoptotic signal mediated by all death receptors (DRs) of the TNF receptor superfamily (Chinnaiyan et al, 1996; Kuang et al, 2000), its regulation of expression was a good candidate. Indeed, the absence of FADD can confer numerous advantages to tumour cells including multiple resistance to DRs and some anticancer drugs (Micheau et al, 1997), acquired ability to coexpress DRs and ligands, and a proliferative advantage (Tourneur et al, 2003). Furthermore, we previously confirmed that FADD can also act as a tumour suppressor (Newton et al, 2000; Tourneur et al, 2005) by showing that (1) FADD protein could be lost in vivo in mouse thyroid adenoma/ADC cells and human acute myeloid leukaemia cells, (2) Fas signalling, in absence of FADD, led to an accelerated growth of thyrocytes, and (3) low level or absence of FADD in leukaemia cells at diagnosis was of poor prognosis in patients' chemotherapy response (Tourneur et al, 2003; Tourneur et al, 2004).

The FADD protein is located both in the cytoplasm and nucleus of most cells (Gomez-Angelats and Cidlowski, 2003; Screaton et al, 2003; Tourneur et al, 2009). Recently, we and others ascertained a new localisation site and regulatory mechanism for the protein (Tourneur et al, 2008),(Kriebardis et al, 2008). We demonstrated that FADD could be held within plasma membrane-derived 
microvesicles, and rapidly released in the extracellular compartment following shedding of these vesicles. Moreover, we showed that adenosine receptors (AR) are implicated in this process. We showed that treatment with $A_{3} A R$ inhibitor but not $A_{1} A R$, $\mathrm{A}_{2 \mathrm{a}} \mathrm{AR}$, and $\mathrm{A}_{2 \mathrm{~b}} \mathrm{AR}$ inhibitors triggers FADD release from mouse lung (Tourneur et al, 2008), demonstrating that in the lung FADD secretion is a regulated process.

Herein, we tested the hypothesis that FADD release could occur during lung cancer and be a useful marker in NSCLC. To do so, we analysed a prospective cohort of 50 NSCLC patients.

\section{PATIENTS AND METHODS}

\section{Patients}

Human primary lung tumour biopsies from 50 successive NSCLC patients were collected at the Hôtel-Dieu hospital and the Institut Mutualiste Montsouris between April 2008 and 2009, during the course of complete surgical resection of their tumours (stages I-III), including multilevel lymph node sampling or lymphadenectomy. For each patient, distant lung tissue (taken at $8-10 \mathrm{~cm}$ from the primary tumour) was used as non-tumoural (NT) tissue. Early metastatic invasion was defined by the presence of blood and/or lymphatic vascular emboli (BVE/LVE). The TNM stage and BVE/ LVE status of the tumours were determined from the histopathological reports obtained at the time of resection. Histopathological and clinical findings were scored according to staging system of the American Joint Committee for Cancer Staging and End Results Reporting, and the TNM staging system of the Union Internationale Contre le Cancer (Mountain, 1997). The main clinical and pathological features of the patients are presented in Table 1. All patients' identities were coded to protect confidentiality. Consent was obtained from all patients and the study was approved by the local ethical committee (Agreement 2007A00845-48).

Table I Patients characteristics

\begin{tabular}{|c|c|c|}
\hline Category & Subcategory & $\begin{array}{l}\text { All patients with } \\
\text { NSCLC }(n=50)\end{array}$ \\
\hline \multirow[t]{2}{*}{ Surgery, $n$} & $\mathrm{HDH}$ & 28 \\
\hline & IMM & 22 \\
\hline \multirow[t]{2}{*}{ Sex, $n(\%)$} & Male & $32(64 \%)$ \\
\hline & Female & $18(36 \%)$ \\
\hline \multirow[t]{2}{*}{ Age, year } & Mean & 63,4 \\
\hline & Range & $44-82$ \\
\hline \multirow[t]{4}{*}{ Smoking history, $n$} & Never smoker & 21 \\
\hline & Passive smoker & I \\
\hline & Smoker & $28(56 \%)$ \\
\hline & Pack/year, $n$ & 40 (mean) $5->80$ (range) \\
\hline Preoperative chemotherapy, $n$ (\%) & Yes & $8(16 \%)$ \\
\hline \multirow[t]{3}{*}{ Histological type, n (\%) } & ADC & $29(58 \%)$ \\
\hline & SCC & $13(26 \%)$ \\
\hline & LCC & $8(16 \%)$ \\
\hline \multirow[t]{10}{*}{ Stage, $n(\%)$} & I & $19(38 \%)$ \\
\hline & IA & 6 \\
\hline & $\mathrm{IB}$ & 13 \\
\hline & $\|$ & II (22\%) \\
\hline & $\| A$ & 0 \\
\hline & $\| \mathrm{B}$ & | | \\
\hline & III & $20(40 \%)$ \\
\hline & IIIA & 15 \\
\hline & IIIB & 5 \\
\hline & IV & 0 \\
\hline
\end{tabular}

Abbreviations: NSCLC $=$ non-small cell lung cancer; $A D C=$ adenocarcinoma; $\mathrm{SCC}=$ squamous cell carcinoma; $\mathrm{LCC}=$ large cell carcinoma; $\mathrm{HDH}=$ Hôtel-Dieu Hospital; IMM = Institut Mutualiste Montsouris; pTNM= pathologic TNM stage. Neoadjuvant chemotherapy was based on platinum salt regimens.

\section{Immunohistochemistry}

Immunostaining with FADD antibody was performed on paraffin sections of lung tumour and distant non-tumour tissues. After antigen retrieval, FADD antibody (mouse monoclonal anti-hFADD (clone 64A6, Abcam, Cambridge, UK), 1:50 dilution) was applied and revealed with a streptavidin-biotin-peroxidase kit (BIOSPA, Abcys, Paris, France). Peroxidase activity was revealed using diaminobenzidine (Dako Cytomation, Glostrup, Denmark). Tissue sections were then counterstained with Harris haematoxylin (Sigma-Aldrich chimie SARL, Saint Quentin Fallavier, France), and slides were mounted with Glycergel Mounting Medium (Dako Cytomation) and visualised by light microscopy (Axiovert II, Leica, Solms, Germany). Blinded examination of sections was done by an experienced lung pathologist (DD).

\section{In vitro culture of human lung biopsies}

All tumours and distant normal lung tissues were obtained immediately at the time of surgery and transported on ice to the laboratory in RPMI 1640 medium. Lung biopsies were stored at $4{ }^{\circ} \mathrm{C}$ and treated 1 day after surgery, after we have checked that storage did not modify the FADD release process. Small lung samples $\left(1-5 \mathrm{~mm}^{3}\right)$ were incubated in $200 \mu \mathrm{l}$ PBS medium in the upper side of a trans-well membrane with $0.4 \mu \mathrm{m}$ pores (BD353495, Becton Dickinson, Franklin Lakes, NJ, USA) to avoid red blood cells contamination. Lower side of the trans-well initially contained $100 \mu \mathrm{l}$ PBS medium. After $1 \mathrm{~h}$ incubation at room temperature, culture mediums were collected in the lower side of the membrane and their volume measured. Lung culture mediums were kept at $-20^{\circ} \mathrm{C}$ until FADD detection was performed. One hour-incubated lung samples were removed and kept at $-20^{\circ} \mathrm{C}$ until protein extraction was performed.

\section{Protein extraction and dosage}

Total cytoplasmic proteins were extracted from lung samples using lysis buffer ( $10 \mathrm{~mm}$ Tris- $\mathrm{HCl}, 50 \mathrm{~mm} \mathrm{NaCl} \mathrm{pH} \mathrm{7.4,} 1 \%$ Triton X100, containing a cocktail of protease inhibitors) and tissue homogeniser MP FastPrep-24 (MP Biomedicals SARL, Illkirch, France). Protein extract volume was measured and sample concentration was determined using the Bradford protein assay. We then calculated the total cytoplasmic proteins quantity in each lung sample.

\section{Fas-associated death domain protein-specific quantitative sandwich ELISA}

To detect soluble FADD, $2.5 \mu$ l of PBS containing $1 \%$ Tween 20 were added to $50 \mu \mathrm{l}$ of human lung culture mediums that were then heated for $5 \mathrm{~min}$ at $100^{\circ} \mathrm{C}$. The ELISA analysis was conducted using anti-hFADD antibody clone $125-140\left(5 \mu \mathrm{g} \mathrm{ml}^{-1}\right.$ in PBS, Calbiochem-Novabiochem Corp., La Jolla, CA, USA) for coating, PBS 2\% BSA for blocking of non-specific binding sites, antihFADD antibody clone A66-2 $\left(1 \mu \mathrm{g} \mathrm{ml}^{-1}\right.$ in PBS/0.05\% Tween 20/2\% BSA; BD Pharmingen, San Diego, CA, USA) for detection, and peroxidase-conjugated anti-mouse IgG1 antibody $(1: 8000$ in PBS/0.05\% Tween 20/2\% BSA; Caltag, Burlingame, CA, USA) for revelation. The colorimetric reaction was revealed by adding $3,3^{\prime}, 5,5^{\prime}$-tetramethyl-benzidine. Reaction was stopped with $2 \mathrm{~N}$ sulphuric acid and the plates were read at $450 \mathrm{~nm}$ with a Titertek multiscan spectrophotometer (MR5000, Dynatec, Mettmann, Germany). Recombinant human FADD protein (Sigma-Aldrich) was used to perform standard range. As lung biopsies' size varied among the patients, for each lung sample the released FADD protein quantity (in ng) was reported to the total cytoplasm proteins quantity contained within the sample (in $\mathrm{mg}$ ), which reflected the biopsy size. 


\section{Statistical analysis}

Statistical analyses were performed by using the Wilcoxon signedrank test and Mann-Whitney test for paired and unpaired data, respectively. Alternatively, the unpaired Student's $t$-test could be used. $P$ values of $<0.05$ were considered to indicate statistical significance. Correlation analyses using the Spearman method were performed with the $R$ statistical software.

\section{RESULTS}

Fas-associated death domain protein loss by human NSCLC

We investigated FADD protein expression in NSCLC by immunohistochemistry. In distant NT $(n=6)$ lung tissue, FADD protein expression was restricted to bronchial epithelial cells and was never found in normal alveolar epithelial cells (pneumocytes) (Figure 1A). Similarly, in the tumour (T, $n=24)$ area, high and low FADD expression was observed in bronchial and alveolar cells, respectively (Table 2). We found a variable patient-dependent FADD protein expression in tumoural cells (Table 2 and Figure 1B), with sometimes coexistence of both FADD-positive and -negative tumoural cells within the same $\mathrm{T}$ area. In such cases,
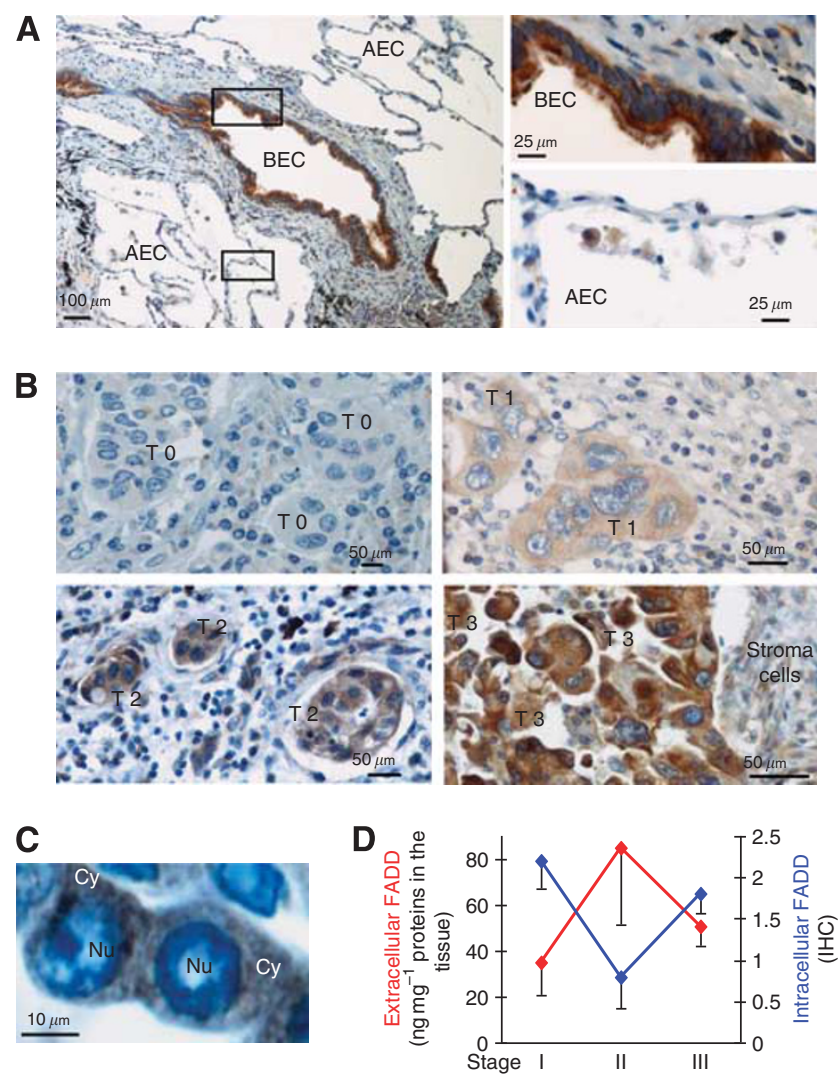

Figure I Loss of FADD in ex vivo NSCLC can result from FADD release. (A-C) Fas-associated death domain protein immunohistochemistry analysis of NT $(\mathbf{A})$ and T tissues (B and $\mathbf{C})$. T0, neg; TI, +; T2, + +; $\mathrm{T} 3,++$ + . A, alveolar; B, bronchial; EC, epithelial cells; Cy, cytoplasm; Nu, nucleus; T, tumour. (D) According to the patients' cancer stage, in vitro T biopsies' FADD release (extracellular FADD) determined by ELISA and ex vivo tumour cells' intracellular FADD expression determined by $I H C$ were inversely correlated ( $n=24$ patients, all from the Hôtel-Dieu). Data represented mean \pm s.e.m. Intracellular FADD expression concerns tumour cells only (not normal epithelial cells). Stage I, II, III: $n=5,6$, and 13, respectively.
FADD was mainly expressed in tumoural cells located at the periphery of the tumour nests (data not shown). Whereas tumoural cells from stage I patients expressed FADD, the expression in tumoural cells from stage II patients was very low to barely detectable (Table 2). However, once the cancer has fully fixed itself (stage III), FADD expression did not decrease anymore. In all cases, we detected FADD expression exclusively in cytoplasm (Figure 1C).

Tumour samples are heterogeneous tissues containing tumoural cells, potentially hyperplastic cells, normal lung cells and immune cells. In light of that, we investigated the release's potential of different areas of a same tumour biopsy. Distant NT tissue that is postulated to contain only normal lung cells was used as control. We detected the FADD protein in the culture medium from both $\mathrm{T}$ and NT NSCLC biopsies (Figure 2A). These results argued for FADD release by human cells in vitro. As expected, FADD release by NT tissues was quite homogeneous for different samples from the same biopsy (mean s.d. $=7.4 \pm 2.9 \mathrm{ng}$ FADD per $\mathrm{mg}$ proteins in the tissue (PT), Figure 2A). In contrast, the amount of FADD released by different areas from the same $\mathrm{T}$ biopsy varied (mean s.d. $=12.3 \pm 3.8 \mathrm{ng} \mathrm{mg}^{-1}$ PT, Figure $2 \mathrm{~A}$ ).

We then investigated FADD release by $\mathrm{T}$ and NT tissues from a 50 NSCLC patients prospective cohort. We detected extracellular FADD protein in the culture medium from both T and NT NSCLC biopsies and showed that $\mathrm{T}$ tissue released significantly more FADD than distant NT tissue (Figure 2B, $P=0.000003$ ). Results obtained by ELISA were confirmed by western blot analysis (Supplementary Figures 1-3). We observed no correlation between

Table 2 Loss of FADD in ex vivo NSCLC

\begin{tabular}{|c|c|c|c|c|}
\hline \multirow[b]{2}{*}{ Patients } & \multirow[b]{2}{*}{ Stage } & \multicolumn{3}{|c|}{ Tumour biopsies intracellular FADD expression ${ }^{a}$} \\
\hline & & Tumour & Alveolar EC & Bronchial EC \\
\hline 35 & 1 & 3 & $\mathrm{np}$ & $\mathrm{np}$ \\
\hline 31 & I & 3 & i & 3 \\
\hline 77 & I & 1.5 & 0 and $\mid$ near $T$ & 3 \\
\hline 76 & । & 2 & 0.5 & 3 \\
\hline 69 & I & 1.5 & 0 & 3 \\
\hline \multicolumn{2}{|c|}{ Mean stage I } & 2.2 & 0.5 & 3 \\
\hline 44 & $\|$ & 0 & 0 and I Hyp & 3 \\
\hline 70 & $\|$ & 0.5 & 0 & $\mathrm{np}$ \\
\hline $30^{\mathrm{b}}$ & $\|$ & 3/ 0 LNM & $2 / 0$ & $3 / 2$ \\
\hline $55^{b}$ & $\|$ & $0.5 / \mathrm{np}$ & 0/ np & $2 / 3$ \\
\hline 50 & $\|$ & 0.5 & 0 & $\mathrm{np}$ \\
\hline $48^{\mathrm{b}}$ & $\|$ & I/ np & $0.5 / 0$ & $1 / 1$ \\
\hline \multicolumn{2}{|c|}{ Mean stage II } & 0.8 & 0.4 & 2.1 \\
\hline 37 & III & 2 & 0 & $\mathrm{np}$ \\
\hline 33 & III & 3 & I & 3 \\
\hline 49 & III & 2 & 0 & 3 \\
\hline $86^{\mathrm{b}}$ & III & $3 / 3$ & $0.5 / \mathrm{np}$ & $2 / 3$ \\
\hline 83 & III & 0 and $2 \mathrm{VE}$ & 0.5 & 3 \\
\hline $82^{b}$ & III & $2 / \mathrm{np}$ & $2 / 0$ & $2.5 / 2$ \\
\hline $68^{\mathrm{b}}$ & III & $2 / 2$ & $\mathrm{np} / \mathrm{np}$ & $\mathrm{np} / \mathrm{np}$ \\
\hline $61^{\mathrm{b}}$ & III & $1.5 / \mathrm{np}$ & $0 / 0$ & $3 / 1$ \\
\hline 87 & III & np & 0 & 3 \\
\hline $88^{b}$ & III & $\mathrm{np} / 2$ & $2 / \mathrm{np}$ & $3 / 3$ \\
\hline $59^{b}$ & III & $\mathrm{np} / 0.5$ & 0 and $2 \mathrm{Hyp} / \mathrm{I}$ & $3 / 3$ \\
\hline 46 & III & । & 1.5 & 2 \\
\hline $28^{\mathrm{b}}$ & III & I/np & $0 / 0$ & $\mathrm{np} / \mathrm{np}$ \\
\hline \multicolumn{2}{|c|}{ Mean stage III } & 1.8 & 0.6 & 2.6 \\
\hline
\end{tabular}

Abbreviations: $\mathrm{EC}=$ epithelial cells; FADD $=$ Fas-associated death domain protein; $\mathrm{np}=$ structure not present in the section; Hyp = hyperplasia; $\mathrm{LNM}=$ lymph node metastasis; $\mathrm{VE}=$ vascular emboli; $\mathrm{T}=$ tumour. Correlation between patients' cancer stage and FADD expression in T area determined by $\mathrm{HC}$. All patients were treated at the Hôtel-Dieu hospital. ${ }^{a} 0$, neg; $0.5, \pm ; 1,+; 1.5,+1++; 2,++; 2.5,++1$ $+++; 3,+++$. Indicates that two samples of a same biopsy were embedded in distinct paraffin blocks that were sectioned and analysed. 
A
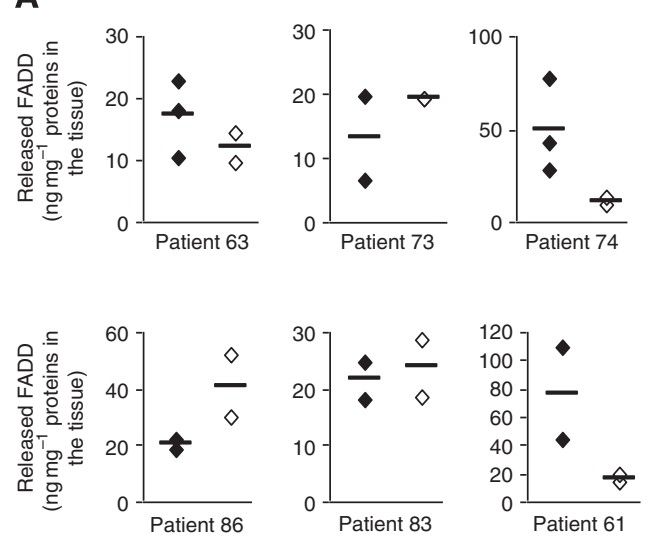
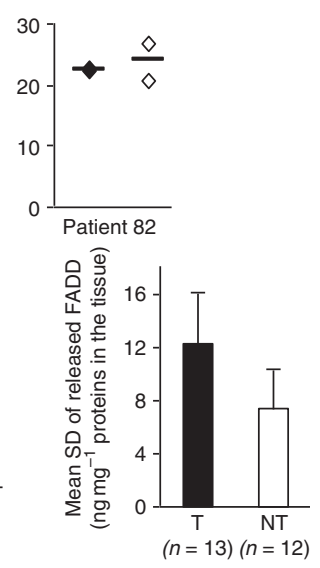

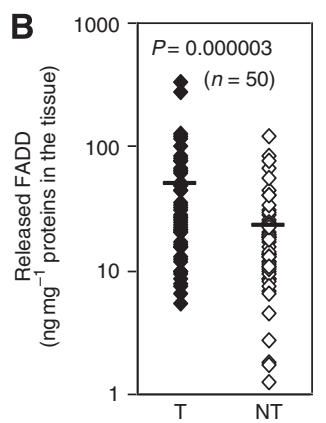

\begin{tabular}{|c|c|c|c|c|c|c|c|c|}
\hline & Hospital & $\begin{array}{l}\text { Chemo- } \\
\text { therapy }\end{array}$ & $\begin{array}{l}\text { Tumour } \\
\text { necrosis }\end{array}$ & Tobacco & $\begin{array}{l}\text { Pack } \\
\text { year }\end{array}$ & Sex & Age & $\begin{array}{c}\text { Released } \\
\text { FADD }\end{array}$ \\
\hline Hospital & 1.00 & 0.33 & 0.24 & -0.14 & 0.39 & 0.05 & 0.02 & -0.12 \\
\hline Chemother & 0.33 & 1.00 & 0.10 & -0.15 & 0.17 & -0.17 & -0.10 & -0.08 \\
\hline T necrosis & 0.24 & 0.10 & 1.00 & -0.09 & 0.25 & 0.12 & 0.20 & -0.15 \\
\hline Tobacco & -0.14 & -0.15 & -0.09 & 1.00 & -0.35 & -0.10 & 0.41 & 0.05 \\
\hline Pack year & 0.39 & 0.17 & 0.25 & -0.35 & 1.00 & -0.25 & -0.13 & 0.12 \\
\hline Sex & 0.05 & -0.17 & 0.12 & -0.10 & -0.25 & 1.00 & -0.09 & -0.29 \\
\hline Age & 0.02 & -0.10 & 0.20 & 0.41 & -0.13 & -0.09 & 1.00 & 0.08 \\
\hline Rel FADD & -0.12 & -0.08 & -0.15 & 0.05 & 0.12 & -0.29 & 0.08 & 1.00 \\
\hline
\end{tabular}

D

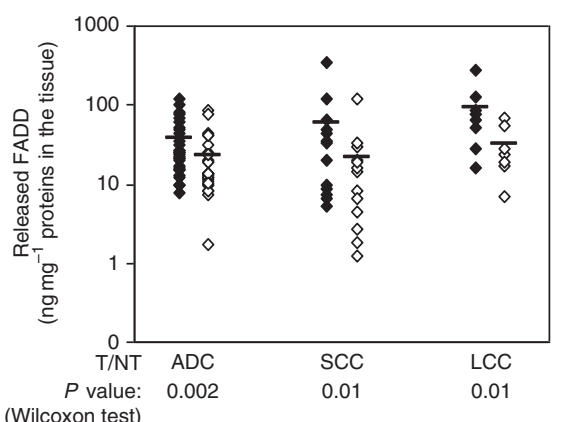

E

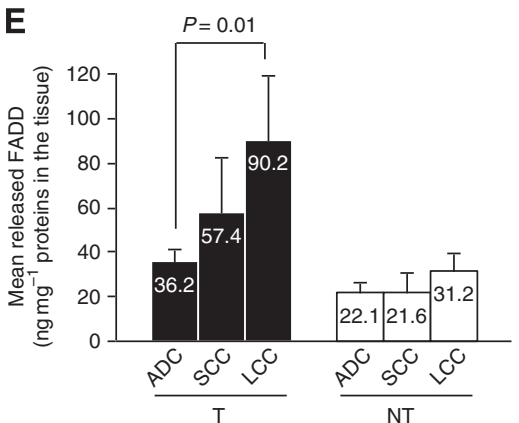

Figure 2 Fas-associated death domain protein is released by human NSCLC. The amount of FADD released by T (black) and by distant NT (white) biopsies in vitro was determined by ELISA. (A) Fas-associated death domain protein release by different samples (diamond) of the same biopsy is shown for seven patients. Bars represent the mean value for each patient. Histogram represents the mean s.d. of FADD release for $T$ and NT patients. (B) Fas-associated death domain protein release by T and NT biopsies from 50 NSCLC patients. When several samples of a same biopsy were tested, we used the samples' mean value. Each diamond represents a patient. Bars represent the mean value for the entire cohort. $P$ values were determined using the Wilcoxon signed-rank test. Range for T and NT biopsies were from 5.3 to 339.7 and 1.2 to $122.5 \mathrm{ng} \mathrm{mg}^{-1}$ PT, respectively. (C) Spearman's correlation. (D and E) Fas-associated death domain protein release depends on the NSCLC histological type. Levels of released FADD determined in Figure 2B were reanalysed after the 50 NSCLC patients were classified according to their histological type. Each diamond represents a patient biopsy ( $T$ in black, NT in white). Bars represent the mean value $(\mathbf{D})$. Histograms represent the mean released FADD value \pm s.e.m. $P$ values were determined using the Mann-Whitney test (E).

FADD release by lung biopsies and patient's hospital, sex, age, chemotherapy, tobacco consumption, or tumour necrosis state (Spearman's correlation test, Figure 2C).

\section{Presence of extracellular FADD in human NSCLC culture depends on the histological type}

We investigated whether FADD release differed according to histological type. We observed that $\mathrm{T}$ biopsies released significantly more FADD than NT biopsies, and this independently of the histological type (Figure 2D). The NT biopsies from ADC, SCC, and LCC patients released similar level of FADD (Figure 2E). Despite being a morphologically and clinically heterogeneous disease, ADC was the NSCLC with the most reproducible extracellular FADD level, demonstrating that the differentiation state of ADC did not influence the FADD release process (Figure 2D). Moreover, T ADC was the histological type releasing significantly the least FADD, whereas T LCC was the one releasing the most $(P=0.01$, Figure $2 \mathrm{E})$.

\section{Presence of extracellular FADD in human NSCLC culture is correlated with patients' cancer stage}

To investigate whether FADD release could be involved in tumour progression and aggressiveness, we looked for a correlation between extracellular FADD level and patients' cancer stage. We showed that FADD release by both $\mathrm{T}$ and NT biopsies increased with the cancer stage (Figure $3 \mathrm{~A}$ and $\mathrm{B}$ ), suggesting that extracellular FADD could be a poor prognostic marker. Fas-associated death domain protein increase was significant for 
A

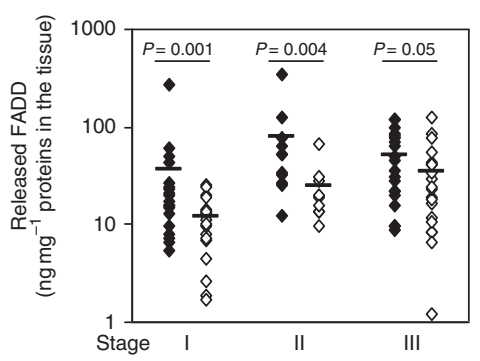

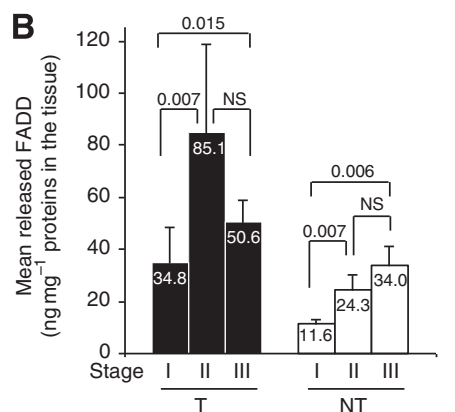

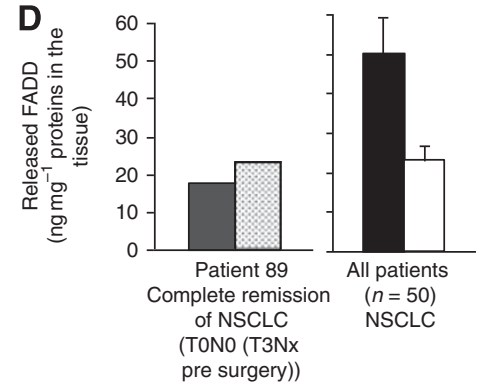

Figure 3 Fas-associated death domain protein release is correlated with cancer development. (A-C) Fas-associated death domain protein release is correlated with patients' cancer stage. Levels of released FADD determined in Figure 2B were reanalysed after the 50 NSCLC patients were classified according to their cancer stage. Each diamond represents a patient biopsy ( $T$ in black, $N T$ in white). Bars represent the mean value. $P$ values were determined using the Wilcoxon signed-rank test $(\mathbf{A})$. Histograms represent the mean released FADD value \pm s.e.m. $P$ values were determined using the Mann-Whitney test (B). (D) Patient 89 is a 54-year-old smoking (60 pack per year) man. Surgical resection of brain metastasis was performed in 2007 , followed by 2 years of radiotherapy and chemotherapy. Fas-associated death domain protein release by remitted tumour (dark grey) and adjacent parenchyma (light grey) biopsies following I-h in vitro culture was determined by ELISA, and was compared with the mean level of FADD released by the 50 NSCLC T (black) and NT (white) biopsies. Abbreviation: NS = not significant.

T biopsies between stages I/II $(P=0.007)$, and I/III $(P=0.015)$, but was no more significant between stages II/III $(P=0.4)$ (Figure $3 \mathrm{~B}$ ). Moreover, the highest level of FADD was released by stage II $\mathrm{T}$ biopsies, which corresponds to the stage where the lowest cellular FADD expression was observed (Figure 1D).

We found that distant lung tissue, which was classified as nontumour tissue, acquired the ability to release high level of FADD during the course of tumour progression (Figure $3 \mathrm{~A}$ and $\mathrm{B}$ ). Confirming this data, we observed that although stage I $\mathrm{T}$ tissue released significantly more FADD than distant NT tissue $(P=0.001)$, the difference between $\mathrm{T}$ and NT released FADD level decreased with cancer progression (Figure $3 \mathrm{~A}$ ). These results were confirmed using the ISSLC stage grouping of the TNM subsets (Figure 3C). Furthermore, we observed that lung biopsies from patient 89 who had achieved complete remission following radiotherapy and chemotherapy, released low level of FADD (Figure 3D). Altogether, these results hinted that FADD release increased during tumour development, accordingly to the cancer stage, and returned to the basal level following complete remission.

\section{Presence of extracellular FADD in human NSCLC culture is correlated with early and late steps of the metastasis process}

Early steps of the metastasis process include blood and lymphatic vascular emboli that can arise within the tumour or at its periphery. The $\mathrm{T}$ biopsies from patients with lung vascular emboli released a higher level of FADD than those of unaffected counterparts (Figure $4 \mathrm{~A}, P=0.04)$. Whatever its type (BVE/LVE) and localisation (intra/peri-tumour), the emboli was always correlated with an increased amount of extracellular FADD (Supplementary Tables 1 and 2). Distant NT biopsies from NSCLC patients with lung emboli released amount of FADD equivalent to $\mathrm{T}$ biopsies from patients without emboli ( $\mathrm{T}(\mathrm{A}) v s \mathrm{NT}(\mathrm{P}))$. These results confirmed that invasive/aggressive tumour (i.e., able to form distant metastasis) affected distant 'non-tumour' lung tissue that behaved like $\mathrm{T}$ tissue regarding FADD release. These results suggested that FADD release by T/NT biopsies and vascular emboli formation are positively correlated.

Late steps of the metastasis process include the formation of regional lymph node metastasis ( $\mathrm{N}$ status). Tumour tissue released more FADD than distant NT tissue. The T/NT difference was even more significant for N0 patients who did not have lymph node metastasis (Figure $4 \mathrm{~B}, P=0.01$ ). However, the difference between $\mathrm{T}$ and NT release waned until becoming insignificant for patients with regional lymph node metastasis (Figure 4B, N1 and N2). In addition, a relevantly higher level of FADD was released by $\mathrm{T}$ biopsies from patients with lymph node metastasis $(\mathrm{N}+)$ than patients without (N0), and the same result was observed for NT biopsies ( $P=0.03$ and $P=0.02$, respectively) (Figure $4 \mathrm{C}$ ). These results demonstrated that increased aggressiveness of the tumour, characterised by regional lymph node metastasis, was correlated with a strong increase in the ability of $\mathrm{T}$ as well as distant NT tissues to release FADD.

\section{DISCUSSION}

The overall data, obtained in a prospective cohort of patients, showed that FADD release by both $\mathrm{T}$ and NT biopsies was positively correlated with the patients' cancer stage, the early and late steps of the metastasis process, and the histological type (Figure 2D, E, 3 and 4). Moreover, the data described herein brings an explanation for intracellular FADD loss by human NSCLC tissues that could result from FADD release. As patient's TNM stage, presence of tumour vascular emboli, lymph node metastasis, and histological type are poor prognostic factors, the ability of lung tissue to release FADD appeared as a poor prognostic marker. 

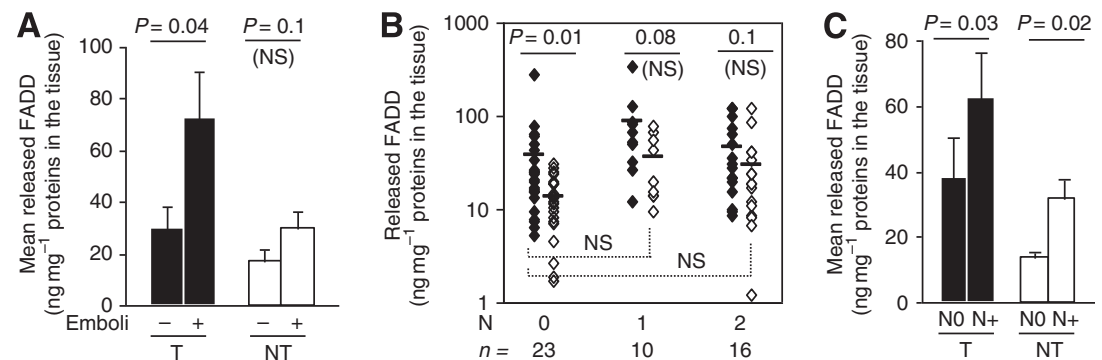

Figure 4 Fas-associated death domain protein release is correlated with cancer aggressiveness. (A-C) Fas-associated death domain protein release by human NSCLC is positively correlated with the presence of vascular emboli and the lymph node invasion. (A) For 26 patients of the cohort, the level of released FADD is correlated with the presence $(+, n=22)$ or absence $(-, n=4)$ of vascular emboli. For other patients, histopathological report gave no information on the presence or absence of emboli. (B and $\mathbf{C}$ ) Levels of released FADD determined in Figure 2B were reanalysed after the 50 NSCLC patients were classified according to their lymph node invasion status. Each diamond represents a patient biopsy ( $T$ in black, NT in white). Bars represent the mean value. $n$ represents the number of patients; one patient with N3 NSCLC is not represented. $P$ values were determined using the Wilcoxon signed-rank test $(\mathbf{B})$. Histograms represent the mean released FADD value \pm s.e.m. of biopsies from $\mathrm{N} 0(n=23)$ and $\mathrm{N}+(n=26)$ patients $(\mathbf{C})$. $P$ values were determined using the Mann-Whitney test $(\mathbf{A}, \mathbf{C})$. Abbreviation: NS= not significant.

As we performed a prospective study, all patients were alive at the time of the study. Consequently, at the present time we could not correlate presence of extracellular FADD and patients' overall survival.

We first investigated FADD protein expression in NSCLC and found a variable cancer stage-dependent FADD protein expression in tumoural cells, with a very low expression in tumoural cells from stage II patients. In lung ADC, FADD protein phosphorylation and nuclear localisation have been associated with aggressive cancer and poor prognosis (Bhojani et al, 2005; Chen et al, 2005). Therefore, it is likely that different mechanisms might be involved to regulate FADD expression or activity in NSCLC. Overexpression of phosphorylated nuclear FADD in cancer cells could lead to NF-kB activation and higher proliferation rate (Bhojani et al, 2005; Chen et al, 2005). However, we showed that, alternatively, FADD could be underexpressed in cancer cells cytoplasm, thus conferring survival advantages through DRs-induced apoptosis resistance. Moreover, the very low expression observed in stage II cancer cells suggested that downregulation of FADD could be a mechanism contributing to disease development, probably more importantly during early (from I to II) than late (from II to III) stages of cancer development.

Several mechanisms could explain the presence of extracellular FADD in cultured NSCLC. We primarily hypothesised that FADD release was the result of cells dying within a tumour. However, the release of FADD started as soon as 5 min of biopsies' incubation (Supplementary Figure 4), and in vitro incubation of lung biopsies never exceeded $1 \mathrm{~h}$, which did not seem sufficient to induce a massive cell death. In accordance with this assumption, and independently of the level of FADD released, we observed only a slight activation of caspase 8 during FADD release, and no LDH (which is released upon cell lysis) could be detected in the culture medium from 1-h incubated NSCLC tumour biopsies (Supplementary Figure 5). Moreover, FADD release was not correlated with the necrosis state of the tumour (Figure 2C). Then, considering the results previously obtained in mouse normal lung (Tourneur et al, 2008), we hypothesised that FADD release from human NSCLC could occur by the means of secretion. In accordance with this hypothesis, we found that FADD could be specifically lost in tumoural cells (Table 2), and the highest level of FADD was released by stage II' T biopsies, which corresponds to the stage where the lowest cellular FADD expression was observed (Figure 1D). These data showed that, in tumour tissues, released and cellular FADD amounts were negatively correlated, suggesting that the release of FADD could much more be a mechanism accounting for cytoplasmic FADD loss than any type of cell death affecting specifically and in a stage-dependent manner the lung cancer cells.
Considering the key role played by FADD in signal transduction (Newton et al, 1998; Yeh et al, 1998; Zhang et al, 1998; Newton et al, 2000; Beisner et al, 2003; Hua et al, 2003; Screaton et al, 2003; Balachandran et al, 2004; Ma et al, 2004; Pyo et al, 2005; Tourneur et al, 2005; Bell et al, 2008; Tourneur and Chiocchia, 2010), the latter's release could modulate several essential biological processes. The significant higher level of FADD released by $\mathrm{T}$ tissue compared with NT tissue suggests that FADD release could be a regulated process preferentially occurring in pathological conditions, and thus potentially contributing to cancer. These results obtained in human NSCLC are in accordance with those obtained in mice showing that FADD secretion does not occur spontaneously but rather in a controlled manner in the lung (Tourneur et al, 2008). The fact that human biopsies are not taken from healthy lungs but at a distance from the tumour could explain the discrepancy between the lack of secretion by normal mouse tissue and the observed release by human NT lungs. One other possibility is a differential regulation of such process in humans and mice. It is also possible that the tumour environment either influences, modifies, or even enables the NT tissue to release FADD. The presence of hyperplastic cells observed in some NT biopsies (not shown) could support the latter hypothesis. Data showing that FADD release by NT biopsies evolved similarly to FADD release by $\mathrm{T}$ biopsies, although the level of released FADD was lower, seemed appealing in that sense (Figures 3 and 4). In light of these data, we must heed the bias existing in using NT tissues as control tissues. Moreover, it opens new intriguing questions regarding the consequence of FADD protein release, both for the releasing (survival/growth advantage?) and the surrounding (apoptosis induction/malignant transformation?) cells.

The observation that FADD release by lung biopsies increased with the cancer stage led to the assumption that FADD release may contribute to tumour progression. As the highest level of FADD was released by stage II' T biopsies, FADD release may be more important during early (from I to II) than late (from II to III) stages of cancer development, confirming data obtained with cellular FADD. Undoubtedly, intracellular FADD loss resulting from FADD release could confer survival advantages to tumoural cells by multiple resistance to DRs and simultaneously to immune cells. Moreover, acquired ability to coexpress DRs and death ligands could mount the tumour 'counter-attack' (O'Connell et al, 1996; Niehans et al, 1997; Buzyn et al, 1999). More recently, FADD has been implicated in autophagy (Pyo et al, 2005; Bell et al, 2008). It has been shown that FADD deficiency abrogated autophagic cell death in HeLa cells and promoted hyperautophagy in T cells. Thus, it might be hypothesised that release of FADD leading to intracellular FADD loss could enhance autophagy in NSCLC cells. As autophagy could promote metastasis development by 
protecting stressed tumour cells as they travel through the vasculature (Kenific et al, 2010), it is possible that FADD release could participate to metastasis formation in NSCLC. Consequently, FADD release by tumoural cells could contribute to disease development and blocking FADD release could probably help to inhibit cancer progression. The very low 5-year overall survival of patients (14\%) despite existing treatments stress the prime importance of understanding the molecular mechanisms underlying FADD release, as involved molecules could constitute potential therapeutic targets that could improve health benefits.

The abovementioned ability of $\mathrm{T}$ and distant NT biopsies to release FADD seemed to be poorly correlated with an increase in tumour size (T status, Supplementary Figure 6), but instead was correlated with the potential of tumoural cells to invade the lymph nodes ( $\mathrm{N}$ status) (Figure $4 \mathrm{~B}$ and $\mathrm{C}$ ). This is undeniably of importance as the NSCLC patients' 5-year survival rate dramatically decreases to $10-30 \%$ when lymph nodes are invaded by the tumour $(\mathrm{N}+$ patients $)$. By the same way, FADD release by T/NT biopsies and vascular emboli formation are positively correlated (Figure 4A). This result was interesting as the presence of intratumour, peritumour, or both neoplastic vascular emboli was linked to declined 5-year survival of NSCLC patients (24\% vs $43 \%$ in absence of emboli) (Alifano et al, 2009). Our data pointed out

\section{REFERENCES}

Alifano M, Cusumano G, Strano S, Magdeleinat P, Bobbio A, Giraud F, Lebeau B, Regnard JF (2009) Lobectomy with pulmonary artery resection: morbidity, mortality, and long-term survival. J Thorac Cardiovasc Surg 137(6): 1400-1405

Balachandran S, Thomas E, Barber GN (2004) A FADD-dependent innate immune mechanism in mammalian cells. Nature 432(7015): 401-405

Beisner DR, Chu IH, Arechiga AF, Hedrick SM, Walsh CM (2003) The requirements for Fas-associated death domain signaling in mature $\mathrm{T}$ cell activation and survival. J Immunol 171(1): 247-256

Bell BD, Leverrier S, Weist BM, Newton RH, Arechiga AF, Luhrs KA, Morrissette NS, Walsh CM (2008) FADD and caspase- 8 control the outcome of autophagic signaling in proliferating T cells. Proc Natl Acad Sci USA 105(43): 16677-16682

Bhojani MS, Chen G, Ross BD, Beer DG, Rehemtulla A (2005) Nuclear localized phosphorylated FADD induces cell proliferation and is associated with aggressive lung cancer. Cell Cycle 4(11): 1478-1481

Buzyn A, Petit F, Ostankovitch M, Figueiredo S, Varet B, Guillet JG, Ameisen JC, Estaquier J (1999) Membrane-bound Fas (Apo-1/CD95) ligand on leukemic cells: a mechanism of tumor immune escape in leukemia patients. Blood 94(9): 3135-3140

Chen G, Bhojani MS, Heaford AC, Chang DC, Laxman B, Thomas DG, Griffin LB, Yu J, Coppola JM, Giordano TJ, Lin L, Adams D, Orringer MB, Ross BD, Beer DG, Rehemtulla A (2005) Phosphorylated FADD induces NF-kappaB, perturbs cell cycle, and is associated with poor outcome in lung adenocarcinomas. Proc Natl Acad Sci USA 102(35): 12507-12512

Chinnaiyan AM, Tepper CG, Seldin MF, O'Rourke K, Kischkel FC, Hellbardt S, Krammer PH, Peter ME, Dixit VM (1996) FADD/MORT1 is a common mediator of CD95 (Fas/APO-1) and tumor necrosis factor receptor-induced apoptosis. J Biol Chem 271(9): 4961-4965

Gomez-Angelats M, Cidlowski JA (2003) Molecular evidence for the nuclear localization of FADD. Cell Death Differ 10(7): 791-797

Hua ZC, Sohn SJ, Kang C, Cado D, Winoto A (2003) A function of Fasassociated death domain protein in cell cycle progression localized to a single amino acid at its C-terminal region. Immunity 18(4): 513-521

Kenific C, Thorburn A, Debnath J (2010) Autophagy and Metastasis: another double-edged sword. Curr Opin Cell Biol 22(2): 241-245

Kriebardis AG, Antonelou MH, Stamoulis KE, Economou-Petersen E, Margaritis LH, Papassideri IS (2008) RBC-derived vesicles during storage: ultrastructure, protein composition, oxidation, and signaling components. Transfusion 48(9): 1943-1953

Kuang AA, Diehl GE, Zhang J, Winoto A (2000) FADD is required for DR4and DR5-mediated apoptosis: lack of trail-induced apoptosis in FADD-deficient mouse embryonic fibroblasts. I Biol Chem 275(33): 25065-25068 that the level of released FADD by $\mathrm{T}$ biopsies and the patients 5 -year survival rate were inversely correlated, confirming that FADD release may have an important role in tumour aggressiveness and may be used as a poor prognostic marker.

\section{ACKNOWLEDGEMENTS}

We thank Patricia Bonjour and Béatrice Marmey for performing paraffin-embedded sectioning and immunostaining, respectively. We are grateful to Valérie Vilmont for critical reading of the manuscript. This work was supported by the Ligue Nationale Contre le Cancer, Comité de Paris, through Grant LNCC No. RS09/ 75-86; and by the Institut National de la Santé et de la Recherche Médicale, the Paris Descartes University, and the Pierre et Marie Curie University.

\section{Conflict of interest}

The authors declare no conflict of interest.

Supplementary Information accompanies the paper on British Journal of Cancer website (http://www.nature.com/bjc)
Ma Y, Liu H, Tu-Rapp H, Thiesen HJ, Ibrahim SM, Cole SM, Pope RM (2004) Fas ligation on macrophages enhances IL-1R1-Toll-like receptor 4 signaling and promotes chronic inflammation. Nat Immunol 5(4): 380-387 Micheau O, Solary E, Hammann A, Martin F, Dimanche-Boitrel MT (1997) Sensitization of cancer cells treated with cytotoxic drugs to fas-mediated cytotoxicity. J Natl Cancer Inst 89(11): 783-789

Mountain CF (1997) Revisions in the international system for staging lung cancer. Chest 111(6): 1710-1717

Newton K, Harris AW, Bath ML, Smith KG, Strasser A (1998) A dominant interfering mutant of FADD/MORT1 enhances deletion of autoreactive thymocytes and inhibits proliferation of mature T lymphocytes. EMBO J 17(3): 706-718

Newton K, Harris AW, Strasser A (2000) FADD/MORT1 regulates the pre-TCR checkpoint and can function as a tumour suppressor. Embo J 19(5): 931-941

Niehans GA, Brunner T, Frizelle SP, Liston JC, Salerno CT, Knapp DJ, Green DR, Kratzke RA (1997) Human lung carcinomas express Fas ligand. Cancer Res 57(6): 1007-1012

O'Connell J, O’Sullivan GC, Collins JK, Shanahan F (1996) The Fas counterattack: Fas-mediated $\mathrm{T}$ cell killing by colon cancer cells expressing Fas ligand. J Exp Med 184(3): 1075-1082

Pyo JO, Jang MH, Kwon YK, Lee HJ, Jun JI, Woo HN, Cho DH, Choi B, Lee H, Kim JH, Mizushima N, Oshumi Y, Jung YK (2005) Essential roles of Atg5 and FADD in autophagic cell death: dissection of autophagic cell death into vacuole formation and cell death. J Biol Chem 280(21): 20722-20729

Screaton RA, Kiessling S, Sansom OJ, Millar CB, Maddison K, Bird A, Clarke AR, Frisch SM (2003) Fas-associated death domain protein interacts with methyl-CpG binding domain protein 4: a potential link between genome surveillance and apoptosis. Proc Natl Acad Sci USA 100(9): 5211-5216

Tourneur L, Buzyn A, Chiocchia G (2005) FADD adaptor in cancer. Med Immunol 4(1): 1

Tourneur L, Chiocchia G (2010) FADD: a regulator of life and death. Trends Immunol 31(7): 260-269

Tourneur L, Delluc S, Levy V, Valensi F, Radford-Weiss I, Legrand O, Vargaftig J, Boix C, Macintyre EA, Varet B, Chiocchia G, Buzyn A (2004) Absence or low expression of fas-associated protein with death domain in acute myeloid leukemia cells predicts resistance to chemotherapy and poor outcome. Cancer Res 64(21): 8101-8108

Tourneur L, Mistou S, Michiels FM, Devauchelle V, Renia L, Feunteun J, Chiocchia G (2003) Loss of FADD protein expression results in a biased Fas-signaling pathway and correlates with the development of tumoral status in thyroid follicular cells. Oncogene 22(18): 2795-2804

Tourneur L, Mistou S, Schmitt A, Chiocchia G (2008) Adenosine receptors control a new pathway of fas-associated death domain protein expression regulation by secretion. J Biol Chem 283(26): 17929-17938 
Tourneur L, Schmitt A, Chiocchia G (2009) In vivo localization of Fas-Associated Death Domain protein in the nucleus and cytoplasm of normal thyroid and liver cells. Open Autoimmun $J$ 1: 27-32

Yeh WC, Pompa JL, McCurrach ME, Shu HB, Elia AJ, Shahinian A, Ng M, Wakeham A, Khoo W, Mitchell K, El-Deiry WS, Lowe SW, Goeddel DV,
Mak TW (1998) FADD: essential for embryo development and signaling from some, but not all, inducers of apoptosis. Science 279(5358): 1954-1958

Zhang J, Cado D, Chen A, Kabra NH, Winoto A (1998) Fas-mediated apoptosis and activation-induced $\mathrm{T}$-cell proliferation are defective in mice lacking FADD/Mort1. Nature 392(6673): 296-300

This work is published under the standard license to publish agreement. After 12 months the work will become freely available and the license terms will switch to a Creative Commons Attribution-NonCommercial-Share Alike 3.0 Unported License. 